Appendix

\title{
The European Elections Study 1994
}

\author{
HENK VAN DER KOLK ${ }^{1}$, HERMANN SCHMITT ${ }^{2}$, EVI SCHOLZ ${ }^{2} \&$ \\ JACQUES THOMASSEN ${ }^{1}$ \\ ${ }^{1}$ University of Twente, The Netherlands; ${ }^{2}$ University of Mannheim, Germany
}

\section{Introduction}

This special issue is based on data sets generated by the European Elections Study 1994, a study concerned with political representation and the legitimacy of government in the European Union. The data were collected by two groups of scholars: the Voters Study group and the Elite Study group. The groups co-ordinated their efforts by using equivalent questions in both studies. This appendix addresses the following subjects: the organisation and composition of the two study groups, the contents of the core questionnaire, the fieldwork and response of the Voters Study, the fieldwork and response of the Candidates Study.

\section{Organisation and composition of the study groups}

The core group of the Voters Study consists of Pilar del Castillo (Madrid), Roland Cayrol (Paris), Cees van der Eijk (Amsterdam), Mark Franklin (Houston, TX), Renato Mannheimer (Genova), Michael Marsh (Dublin), Karlheinz Reif (Brussels), Hermann Schmitt (Mannheim), and Colette Ysmal (Paris). This group is co-ordinated by Hermann Schmitt and is supplemented by a number of country specialists: Mario Baccalhau (Lisbon), Michael Guilljam (Göteborg), Ilias Nikolakopoulos (Athens), Lieven De Winter (Louvain), and Torben Worre (Copenhagen).

The Elite Study group consists of Richard Katz (Baltimore, NJ), Pippa Norris (Cambridge, MA), Jacques Thomassen (Enschede), and Bernhard Wessels (Berlin). Hermann Schmitt, co-ordinator of the Voters Study group, is also involved in the work of this group. This second group is also assisted by 


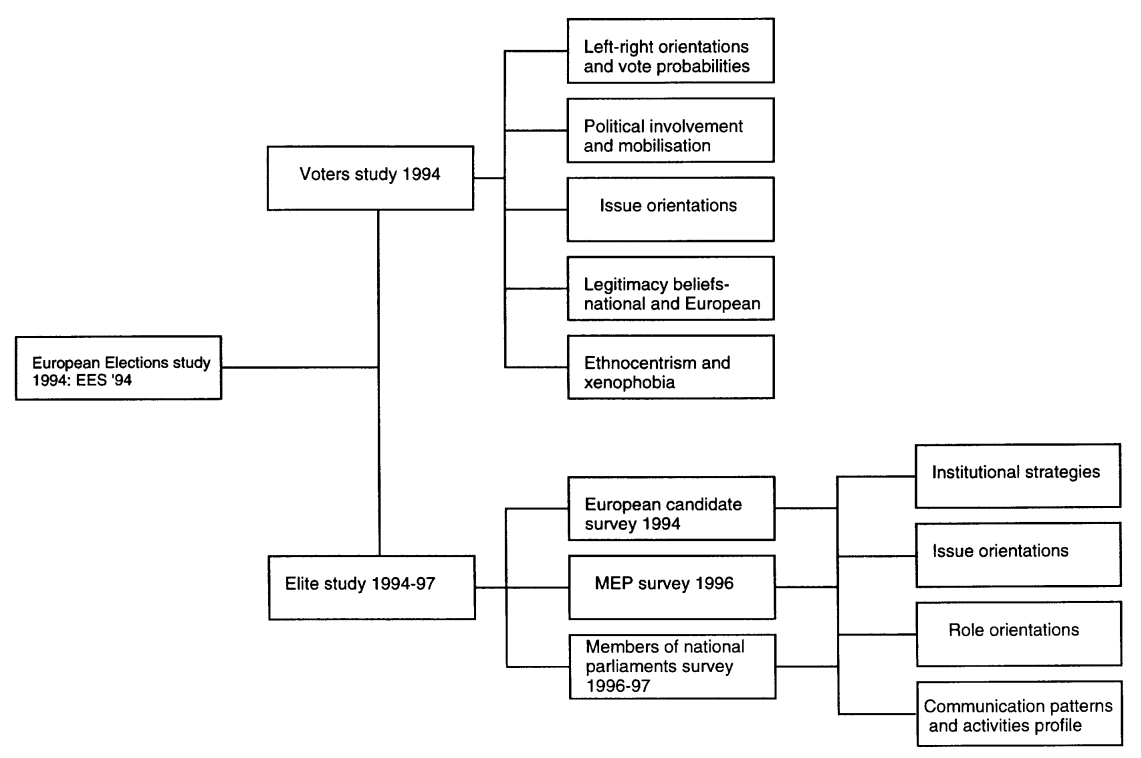

Figure 1. Design of European Elections Study.

a number of country specialists: Lieven De Winter (Louvain), Tom Bryder (Copenhagen), Peter Lynch (Edinburgh), Cecile Chavel (Paris), Michael Marsh (Dublin), Louisa Gardella (Genova), Peter Geurts (Enschede), Maria José Stock (Lisbon), Lourdes Lopez Nieto (Madrid), and Irene Delgado (Madrid).

\section{Plan of the study and publication programme}

Study design and content of the core questionnaires are depicted in the following diagram (Figure 1). It can be seen that the research programme of the European Elections Study 1994 will not be completed with this special issue since there are two further surveys, the MEP survey and the survey among members of national parliaments still be analysed.

This special issue is part of a larger plan to publish the results of the overall study. It compares some of the findings of the Voters and the Candidates Study. Other books are in the pipeline including a concluding column on the overall study, Political Representation in the European Union, to be edited by Hermann Schmitt and Jacques Thomassen. 
Table 1. The INRA network of research institutes, fieldwork dates and sample size

\begin{tabular}{llll}
\hline Country & $\begin{array}{l}\text { National } \\
\text { partner institute }\end{array}$ & $\begin{array}{l}\text { Start - end } \\
\text { fieldwork }\end{array}$ & $\begin{array}{l}\text { Interviews } \\
\text { conducted }\end{array}$ \\
\hline Belgium & Marketing Unit & $13.06 .-30.06$. & 1003 \\
Denmark & GFK Danmark & $11.06 .-28.06$. & 1000 \\
Germany-East & SAMPLE & $13.06 .-05.07$. & 1052 \\
Germany-West & SAMPLE & $13.06 .-02.07$. & 1082 \\
Greece & KEME & $13.06 .-30.06$. & 1002 \\
Spain & CIMEI & $13.06 .-27.06$. & 1000 \\
France & TMO Consultants & $13.06 .-27.06$. & 1000 \\
Ireland & LANSDOWNE Market Research & $13.06 .-08.07$. & 1000 \\
Italy & PRAGMA & $14.06 .-28.06$. & 1067 \\
Luxembourg & ILRES & $13.06 .-08.07$. & 502 \\
Netherlands & NIPO & $11.06 .-02.07$. & 1005 \\
Portugal & NORMA & $15.06 .-04.07$. & 1000 \\
United Kingdom & NOP Corporate and Financial & $13.06 .-07.07$. & 1078 \\
Northern Ireland & Ulster Marketing Services & $14.06 .-30.06$. & 305 \\
\hline
\end{tabular}

\section{Study design: The European Voters Study}

\section{Organisation of the fieldwork}

The Voters Study was carried out in the then twelve member countries of the European Union as a part of a special post-electoral Eurobarometer survey (EB 41.1). This was made possible by the energetic support of the former director of Eurobarometer surveys, Karlheinz Reif, and by grants obtained from the Deutsche Forschungsgemeinschaft and the Nederlandse Stichting voor Wetenschapelijk Onderzoek. Additional support was provided by the University of Mannheim (Mannheimer Zentrum für Europäische Sozialforschung) which serves as the co-ordination center of the study and funded a pretest survey conducted by ZUMA in the Mannheim area, among other things.

The post-electoral Eurobarometer 41.1 carried another academic voting study which explores the reasons of non-voting and is directed by Jean Blondel, Richard Sinnott, and Palle Svensson. Their article in this special issue reports on the findings of this study.

Fieldwork of Standard Eurobarometer surveys is carried out, on behalf of the European Commission, by INRA Europe (International Research Associates). INRA Europe is a European network of market- and public opinion research agencies based in Brussels. Table 1 shows the institutes which con- 
duct the surveys, the fieldwork dates and the number of interviews conducted in each country.

\section{Sampling}

Standard Eurobarometer surveys in each country are based on a multi-stage probability sample. Proportional to population size and population density, sample points are drawn at random. Face-to-face interviews are carried out in the respective national language(s), in the people's homes. The universe of Eurobarometers usually is the resident population of the respective nationality, aged 15 years and above. In some surveys the universe is enlarged to include non-national EU-citizens resident in different member-countries.

\section{Cleaning, storing and accessibility of the data}

The Voters Study of the European Election Study 1994 is included in Eurobarometer 41.1. However, there are other Eurobarometers which include a more limited number of questions on electoral behaviour, and the final dataset of the Voters Study 1994 thus will include three more surveys - parts of two pre-electoral (EB's 40 and 41) and of one other post-electoral Eurobarometer (EB 42) survey(s).

The data-sets are harmonised so that identical variables across the different waves are named and coded and labelled the same. This extends not only across the different surveys included in the 1994 Voters Study, but also back to the 1989 Voters Study data-set. The data-sets will be made available to the scientific community, in 1997 over the social science data archives.

\section{Study design: The European Candidates Study 1994}

\section{Organisation of the fieldwork}

The European Candidates Study was carried out by mail questionnaire just before the European Parliament elections of 1994. Co-ordinated by Jacques Thomassen (University of Twente) and executed by group of scholars with one national study director in each of the then member countries. Data from Portugal came long after the deadline and therefore are not used in this special issue. Data on Greek candidates though reportedly assembled have not yet been obtained. Financial support was provided by the faculty of Public Administration and Public Policy of the University of Twente (for co-ordination, printing of questionnaires and data-processing), and the home institutions of the national study directors (for translation and fieldwork). 
Table 2. Candidates survey: General response information

\begin{tabular}{lccccc}
\hline & $\begin{array}{l}\text { Number of } \\
\text { candidates } \\
\text { (population) }\end{array}$ & $\begin{array}{l}\text { Size of the } \\
\text { sample }\end{array}$ & $\begin{array}{l}\text { Returned } \\
\text { (percent of } \\
\text { population) }\end{array}$ & $\begin{array}{l}\text { Number of } \\
\text { elected } \\
\text { MEPs }\end{array}$ & $\begin{array}{l}\text { Interviewed } \\
\text { (percent of } \\
\text { elected) }\end{array}$ \\
\hline Belgium & 336 & 336 & $117(35 \%)$ & 25 & $10(40 \%)$ \\
Denmark & 183 & & $105(57 \%)$ & 16 & $8(50 \%)$ \\
France & 783 & & $104(13 \%)$ & 87 & $6(7 \%)$ \\
Germany & 1171 & 1171 & $395(34 \%)$ & 99 & $32(32 \%)$ \\
Ireland & 52 & 52 & $12(23 \%)$ & 15 & $1(7 \%)$ \\
Italy & 1308 & 550 & $137(10 \%)$ & 87 & $19(22 \%)$ \\
Luxembourg & 60 & 60 & $33(55 \%)$ & 6 & $4(67 \%)$ \\
Netherlands & 246 & 202 & $125(51 \%)$ & 31 & $21(68 \%)$ \\
Portugal & 316 & 316 & $24(8 \%)$ & 25 & $34(53 \%)$ \\
Spain & 1920 & 320 & $74(4 \%)$ & 64 & $24(29 \%)$ \\
UK (excl. N. Irl.) & 349 & 294 & $134(38 \%)$ & 24 & $162(30 \%)$ \\
Total & 6724 & & $1256(19 \%)$ & 539 & \\
\hline
\end{tabular}

Response analysis

The number of candidates differed drastically from one country to the next. In Ireland there were only 52 candidates, in Spain 1920. Because not all candidates were known when the survey started, not all candidates could be approached, and because some national study directors decided to approach a sample rather than all candidates, the sample universe differed from the actual number of candidates approached. This, however, differs from one country to the next. Also, the intensity and effectiveness of follow-up strategies differed from country to country. For this and other reasons the response rates differed substantially between the countries. The overall results are presented in the first three columns of Table 2.

Data about elected members in the data-set can be compared with population data. Regarding the age of elected candidates, there seem to be no gross misrepresentations of specific age categories in the data-set (Table 3).

The same goes for the gender of respondents. In Table 4, the percentages of male and female representatives in both the data-set and the population are reported.

Further, the variable 'elected before' was compared with population data. Again, we find no gross misrepresentation of the seniority of elected candidates in our sample (Table 5).

Finally the European party group affiliation of our sample and the overall population of MEP's is compared in Table 6. This table shows percentages in 
Table 3. Age of elected representatives (excl. Greece and N. Ireland)

\begin{tabular}{|c|c|c|c|}
\hline \multirow[t]{2}{*}{ Age } & \multirow{2}{*}{$\begin{array}{l}\text { Sample } \\
(\%)\end{array}$} & \multicolumn{2}{|c|}{ Population } \\
\hline & & $\mathrm{N}$ & $(\%)$ \\
\hline $26-35$ & (9.1) & 9 & $(5.7 \%)$ \\
\hline $36-45$ & (22.3) & 44 & $(27.8 \%)$ \\
\hline $46-55$ & (43.4) & 67 & $(42.4 \%)$ \\
\hline $56-65$ & (20.6) & 34 & $(21.5 \%)$ \\
\hline $66+$ & $(4.6)$ & 4 & $(2.5 \%)$ \\
\hline NA & & 4 & \\
\hline
\end{tabular}

Table 4. Sex of elected representatives (excl. Greece and N. Ireland)

\begin{tabular}{lrlll}
\hline \multirow{2}{*}{ Gender } & \multicolumn{2}{c}{ Sample } & \multicolumn{2}{c}{ Population } \\
& $\mathrm{N}$ & $(\%)$ & $\mathrm{N}$ & $(\%)$ \\
\hline Male & 112 & $(70.9 \%)$ & 397 & $(73.8)$ \\
Female & 46 & $(29.1 \%)$ & 141 & $(26.2)$ \\
\hline
\end{tabular}

Table 5. Year of first election (excl. Greece and N. Ireland)

\begin{tabular}{lllll}
\hline Elected before & \multicolumn{2}{c}{ Sample } & \multicolumn{2}{c}{ Population } \\
& $\mathrm{N}$ & $(\%)$ & $\mathrm{N}$ & $(\%)$ \\
\hline Elected before & 79 & $(48.8 \%)$ & 243 & $(45.1 \%)$ \\
New-comer & 83 & $(51.2 \%)$ & 296 & $(54.9 \%)$ \\
\hline
\end{tabular}

Table 6. European party groups (excl. Greece and N. Ireland)

\begin{tabular}{lrlrl}
\hline \multirow{2}{*}{ Party group } & \multicolumn{2}{c}{ Sample } & \multicolumn{2}{c}{ Population } \\
& $\mathrm{N}$ & $(\%)$ & $\mathrm{N}$ & $(\%)$ \\
\hline PES & 62 & $(39.5 \%)$ & 198 & $(34.9 \%)$ \\
EPP & 46 & $(29.3 \%)$ & 157 & $(27.7 \%)$ \\
LDR & 20 & $(12.7 \%)$ & 43 & $(7.6 \%)$ \\
EUL & 6 & $(3.8 \%)$ & 28 & $(4.9 \%)$ \\
FE & 2 & $(1.3 \%)$ & 27 & $(4.8 \%)$ \\
EDA & 2 & $(1.3 \%)$ & 26 & $(4.6 \%)$ \\
Greens & 7 & $(4.5 \%)$ & 23 & $(4.1 \%)$ \\
ERA & 2 & $(1.3 \%)$ & 19 & $(3.4 \%)$ \\
EDN & 5 & $(3.2 \%)$ & 19 & $(3.4 \%)$ \\
Independent & 5 & $(3.2 \%)$ & 27 & $(4.8 \%)$ \\
NA & 5 & & & - \\
Total & 162 & & 267 & \\
\hline
\end{tabular}


the data file and in the population for all groups (again elected candidates only, excluding Greece and Northern Ireland). We find all party groups represented in the data-set, though the larger party groups are somewhat over represented in the realised sample.

Despite their limitations, these findings show the representativeness of the elected candidates in our sample is acceptable for many purposes, at least according to a number of criteria at hand.

Cleaning, storing and accessibility of the data

All questionnaires were printed on machine readable forms. Data-processing was done at the University of Twente. The cleaning of the raw data took place in various stages. Taken into account were wild codes, routing inconsistencies, strange differences between countries, systematically missing categories etc. Alternations were not made until the original questionnaires had been consulted. The data are stored in SPSS files. The full data will not be released to the scientific community at large for reasons of privacy protection.

Address for correspondence: Hermann Schmitt, Mannheimer Zentrum für Europäische Sozialforschung, Universität Mannheim, D-6800 Mannheim, Germany

Phone: +49 621 2921881; Fax: +49 621 2921779; E-mail: hschmitt@mzes.uni-mannheim.de 